\title{
MAPPING THE CONCEPTUAL STRUCTURE OF ENVIRONMENTAL MANAGEMENT: A CO-WORD ANALYSIS
}

\author{
Juan-José NÁJERA-SÁNCHEZ1 , Eva-María MORA-VALENTÍN ${ }^{2}$, \\ Marta ORTIZ-DE-URBINA-CRIADO ${ }^{3}$, Pablo MOURA-DÍEZ ${ }^{4}$
}

\author{
Universidad Rey Juan Carlos, Madrid, Spain \\ E-mails: ${ }^{1}$ juanjose.najera@urjc.es (corresponding author); ${ }^{2}$ evamaria.mora@urjc.es; \\ ${ }^{3}$ marta.ortizdeurbina@urjc.es; ${ }^{4}$ pmoudie@hotmail.com
}

Received 19 August 2018; accepted 27 December 2018

\begin{abstract}
This paper contributes to a better understanding of the research on environmental management using bibliometric methods to supplement the subjective evaluation of literature reviews. Focusing on the Management and Business fields, our main objective is to analyse the knowledge structure of environmental management literature and the evolution of related topics. We apply the co-word analysis method to identify different topics treated by the field across the studied periods, and to create networks and sub-networks. The results show the main topics and their evolution. We identify and explain six topics: green/environmental, resource-based-view, management, performance, corporate social responsibility and quality management. Development in this line of research shows progress in this discipline that commences with the green or environmental dimension and its effects on results and continues with issues that are more focused on quality management and corporate social responsibility. This study can be used as a reference for future research and help to increase company awareness of the importance of environmental issues in the design and implementation of strategies.
\end{abstract}

Keywords: environmental management, environmental strategy, green environment, corporate social responsibility, co-word analysis, bibliometric analysis.

JEL Classification: M10, M14.

\section{Introduction}

The magnitude, timing and importance of current environmental problems require a more holistic analysis of the issues. The causes of these problems include the increase in the world's population, higher consumption of natural resources and the greater environmental impact of social and economic activity (Throop et al. 1993, Shrivastava 1995). A highly significant part of the economic activity and production that results in emissions, waste and dumping in natural environments is carried out by companies, which makes it necessary for them to become part of solving these environmental issues (Banerjee 2001, Darnall et al. 2010).

The study of the role of organizations in the environment has resulted in literature in the field of "organizations and natural environment". Nevertheless, the generic concept most referred to by researchers is that of "environmental management". The literature on environmental management has evolved over time, together with other related concepts such as corporate social responsibility, corporate social performance, sustainable development and business ethics (Carroll 1979, Bansal and Song 2016).

First, we have found several studies that present reviews of the literature on environmental management focusing on a specific area of Management and Business research, such as ecopreneurial businesses (Holt 2011), green supply chain management (Srivastava 2007, Sarkis et al. 2011, Wong et al. 2015, Ciccullo et al. 2018), environmental management system (Ferenhof et al. 2014, Guenther et al. 2016, Salim et al. 2018), environmental management accounting

Copyright @ 2019 The Authors. Published by VGTU Press.

This is an Open Access article distributed under the terms of the Creative Commons Attribution License (http://creativecommons.org/licenses/by/4.0/), which permits unrestricted use, distribution, and reproduction in any medium, provided the original author and source are credited.. 
(Schaltegger et al.2013), relationship between environmental management and results or performance (Ambec and Lanoie 2008, Molina-Azorín et al. 2009a, 2009b, Albertini 2013) and management of human resources and its relationship with environmental management (Renwick et al. 2013, Tariq et al. 2016, Mukherjee and Chandra 2018). However, few of them perform a bibliometric analysis of the literature. Schaltegger et al. (2013) investigate the literature on environmental management accounting from 1973 to 2011 and apply some bibliometric measures to analyse publications, journals, authors and citations. The bibliometric analysis of Ferenhof et al. (2014) focuses on the identification of the most relevant articles, authors, keywords and journals published between 1999 and 2013 to analyse the literature about environmental management systems in small and medium enterprises.

A second type of studies present literature reviews of environmental management from a generic Management and Business perspective. Bansal and Gao (2006) analyse prior research on organizations and environment. They select the articles published in 11 top Management and Business academic journals from 1995 to 2005 and develop descriptive and narrative analyses of journals, biases and trends. Etzion (2007) reviews the academic literature from 1992 to 2006 to present an analysis of environmental issues in organizations using three viewpoints: individual firm (firm attributes and environmental performance); level of industry (individual firm and organizational environment -regulators, customers and competitors-); and organizational environment (actors external to the organization -activists, investors and the media-). But there are no papers that identify the main themes or topics on environmental management that have been studied in the Management and Business fields using bibliometric methods such as citation analysis, co-citation analysis, bibliographic coupling, co-author analysis and co-word analysis.

The approach to studying particular areas of research has been mainly focused on two types of methods: qualitative methods based on a structured review of the literature, and quantitative methods, mainly through meta-analysis. In the latter, the growing importance of bibliometric methods should be highlighted but the least common method has been co-word analysis, especially in the areas of Management and Business (Zupic and Čater 2015). Zupic and Čater (2015) claim that co-word analysis is the only bibliometric technique that deals directly with concepts extracted from documents and therefore studies the structure of knowledge and not the intellectual base.

The main objective of this paper is to analyse the knowledge structure of environmental management literature focused on the Management and Business fields, identifying the main and emerging topics of the field and the evolution of related topics. We apply the co-word analysis method to identify different topics treated by the field across the studied periods, and to create networks and sub-networks. In this sense, co-word analysis allows us to return a set of networks that represent groups of textual information that can be understood as semantic or conceptual groups of different topics by the research field (Cobo et al. 2011). This study may serve as a reference for development in this area of research, offering researchers a map of the current state of literature and a guide for future research. Then, after accomplishing this objective, we will be better able to (a) identify the available evidence relating to environmental management; (b) identify and analyse the thematic networks; (c) explain the major topics; and (d) propose new research questions.

\section{Environmental management}

The concept of environmental management was defined by Wehrmeyer (1996: 12) as "the coordinated and organized approach to issues relating to the natural environment, from a business perspective with the aim of reducing those impacts deemed harmful to the natural environment". Van Marrewijk (2003) highlights the idea of a more ethical, human and transparent way of business management, in academia as in the practitioner's world. In fact, Business \& Society has become a research field in which there are at least five main divisions: a) social corporate responsibility; b) ethics on business; c) sustainability; d) corporate citizenship; and e) stakeholder management (Schwartz and Carroll 2008). Transversally, the theme of Organization \& Environment (a. k. Organizations and Natural Environment) has emerged and consolidated, starting at contributions of multiple disciplines: Sociology, Psychology, Anthropology, Political Science, Ethics, Mathematics and, of course, Economy and Business Administration. This last field has had a special importance, with contributions from the Marketing area, Accountability, Organizational Behaviour, Strategic Management, Operations, and Management Information Systems (Sharma 2002).

Egri and Pinfield (1996) highlight the need for a holistic study, due to the concept's multifaceted, multidisciplinary and controversial nature: multifaceted because it requires different levels of analysis (individual, group, organization, social and global) from different perspectives (Physical, Technical, Social, Economic, Ethical); multidisciplinary because it requires contributions from Natural Sciences (Physics, Chemistry, Biology, Ecology) and Social Sciences (Sociology, Philosophy, Organizational Theory) in order to identify areas of intersection and divergence; and controversial because it is comprised of different political and social stakeholders who propose alternative courses of action and conflicting approaches.

Due to complexity, there have been several approaches to structure the field, usually around several main research 
questions (Sharma 2002, Bansal and Gao 2006, Berchicci and King 2007, Etzion 2007). Three of these questions stand out: 1) What is the environmental strategy and what are the different typologies? 2) What are the reasons companies adopt different environmental strategies? 3) What are the consequences of the environmental strategies?

The main theories from Management and Business fields have been used to explain these questions. Institutional Theory and Stakeholder Theory analyse external factors, although the last one also observes internal agents (managers, employees and shareholders) (Fineman and Clarke 1996, Henriques and Sadorsky 1999, Buysse and Verbeke 2003, Murillo-Luna et al. 2008). Cognitive Approach and Resource Theory focus on internal aspects, like manager perceptions or internal resources of the companies, although external aspects like reputation or legitimacy are also studied (Hart 1995, Russo and Fouts 1997, Sharma and Vredenburg 1998, Menguc and Ozzane 2005).

This research deals with the analysis of the literature that have studied these questions in Management and Business fields, using a quantitative approach, to try to shed light in organizing all of these contributions and give a straightforward scheme of it.

\section{Methodology: co-word analysis}

Co-word analyses study the co-occurrence of pairs of items (for example, keywords) that are representative in a document, to identify relations between the ideas presented in the texts (He 1999). Although there have been several approaches to the study of co-word analysis, we follow the proposal of Cobo et al. (2011). In the first phase, the aim is to group topics within the network of different concepts, which gives rise to sub-networks. With the aim of obtaining bibliographical records related to the field of investigation in environmental management, we decided to consult the Social Science Citation Index of the Web of Science (WoS), a common option used in studies in this field (Zupic and Čater 2015). Given the scope of the study, it was decided to restrict the results to WoS "Management" and "Business" categories and only analyse the articles published in academic magazines at a particular point in time. With these initial conditions, we consulted the keywords chosen in titles, abstracts and keywords in the month of June, 2016 (Table 1).

After determining the base documents, we proceeded to assign representative terms to each one. The final decision was to establish the keywords suggested by WoS as the topic words, given that in spite of the criticism of Kostoff et al. (1997), keywords are useful, provided a standardization process is carried out. In this study, the standardization took place in accordance with the recommendations of Choi et al. (2011). With these terms and the frequencies of occurrence and co-occurrence of each term, the equivalence indexes were calculated. This selection was based on the recommendations of Van Eck and Waltman (2009) and Cobo et al. (2011). The last choice to define the thematic groups in each period was of the algorithm. In this case, we opted for the proposal by Coulter et al. (1998), using the simple centers algorithm, as its results in co-word analyses have been contrasted in many studies (Coulter et al. 1998, Cobo et al. 2011, Cobo et al. 2015).

After obtaining the thematic networks, the analysis of the knowledge structure of the area studied could be performed according to its characterization and a study of the relationships between concepts. Law et al. (1988) originally proposed the idea of a strategic matrix to represent the different topics in a field of study in a bi-dimensional diagram, based on the centrality and density of each sub-network. Callon et al. (1991) highlight four quadrants: the above left side of the matrix represents the highly developed and isolated themes; the down right side, the emerging and declining themes; in the above right side, we see motor themes, and in the down right side, the basic and transversal themes.

Table 1. Search results

\begin{tabular}{|l|c|}
\hline \multicolumn{1}{|c|}{ Keywords } & \# articles \\
\hline "environmental management" & 641 \\
\hline "environmental strategy" & 141 \\
\hline "green management" & 52 \\
\hline "green strategy" & 9 \\
\hline "ISO 14001" & 134 \\
\hline "ISO 14000" & 36 \\
\hline "EMAS" & 5 \\
\hline Combined query & 850 \\
\hline
\end{tabular}

\section{Results}

Figure 1 shows that, until the year 1992, contributions were sporadic and even until 2005, although there is continuity, the barrier of 25 articles per year was not overcome. 1995 is the first year in which the number of articles published, compared to the previous year, is doubled, thanks to the monographic study by the Academy of Management Review on the topic "ecologically sustainable organizations". In 2000, the number of contributions is again doubled with respect to the previous year, largely due to another monographic work, this time published by the Academy of Management Journal on "the management of organizations in the natural environment". From then on, a certain continuity is observed and the evolutionary analysis of the structure of knowledge distinguishes three stages: until 2005, from 2006 to 2010 and from 2011 to 2015.

We analyse the different matrices for each period that enable us to represent and calculate the relations between 


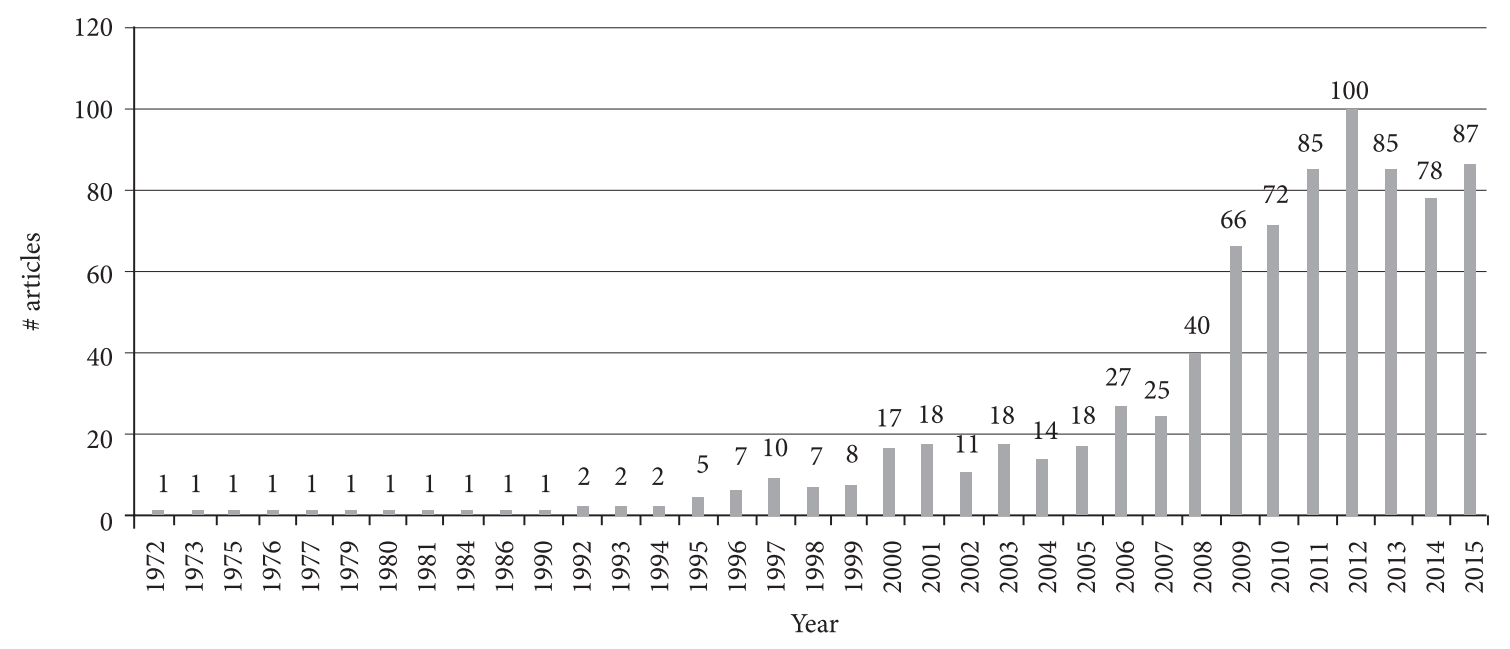

Figure 1. Evolution of scientific literature on environmental management

the different thematic networks at different moments in time. In order to complete the analysis, we included a joint representation of the sub-networks obtained, using VOSViewer and the Kamada-Kawai algorithm to establish the arrangement of the topics, represented by the color of the clusters obtained in the previous step.

For the first period (up to 2005), Figure 2 include the number of documents in which each topic is addressed, represented by the size of the circle. We can observe the existence of two main topics: GREEN/ENVIRONMENTAL/ECOLOGY-ECOLOGICAL and COST and one emerging topic CORPORATE SOCIAL PERFORMANCE. And, TECHNOLOGY sub-network clearly appears as a crosssectional topic.

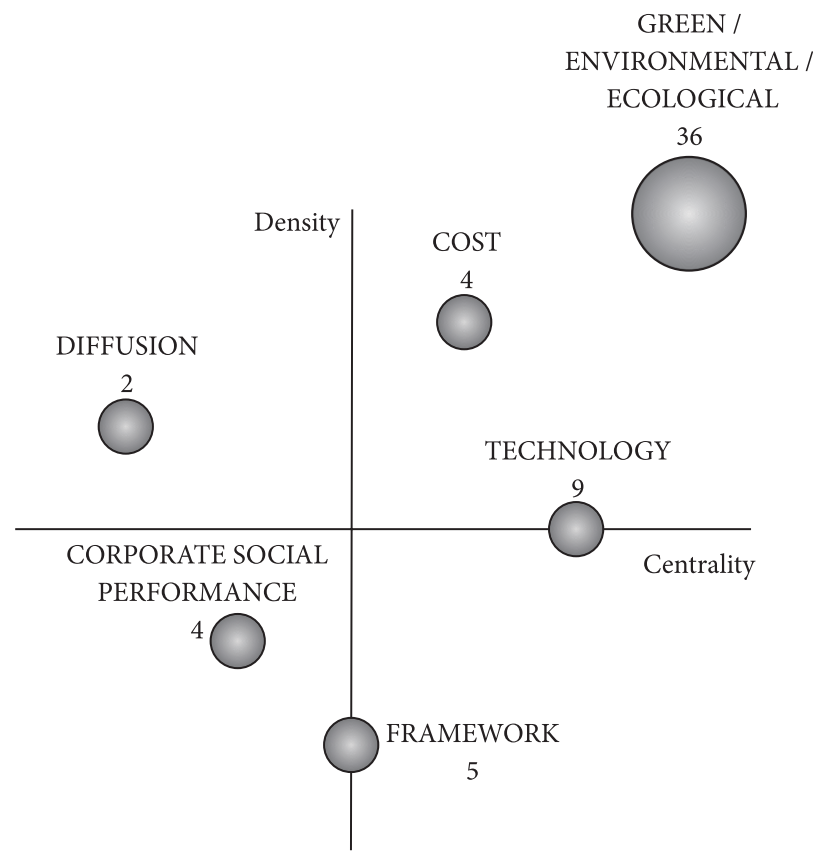

Figure 2. Strategic matrix for first period (up to 2005)
Complete network is presented in Figure 3 that shows the topics linked to GREEN/ENVIRONMENTAL/ECOLOGY-ECOLOGICAL cluster, which includes PERFORMANCE and RESOURCE-BASED-VIEW, in the center of the network (in red). Next to these topics are the topics linked to the TECHNOLOGY sub-network (in blue). This sub-network includes other topics related to OPERATIONS. In a less central position, we observe another two networks: COST, in yellow, and FRAMEWORK, in blue. The CORPORATE SOCIAL PERFORMANCE network (in pink) is more diffuse, with this topic close to the center of the network, and the others much less connected.

Table 2 summarizes the metrics of the networks in this period. We observed that the majority of the topics have a

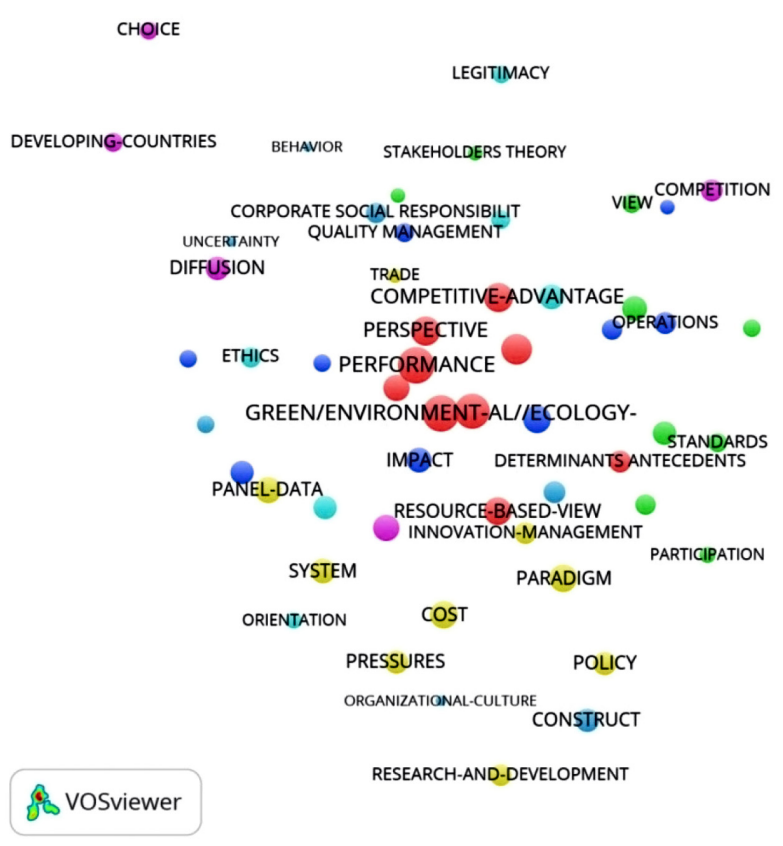

Figure 3. Complete network (up to 2005) 
Table 2. Measurement of topic performance up to 2005

\begin{tabular}{|l|c|c|c|}
\hline \multicolumn{1}{|c|}{ Theme } & \# articles & $\mathrm{h}$ index & Average quotes \\
\hline $\begin{array}{l}\text { GREEN/ENVIRON- } \\
\text { MENTAL//ECOLOGY- } \\
\text { ECOLOGICAL }\end{array}$ & 36 & 29 & 141.47 \\
\hline COST & 4 & 4 & 103.25 \\
\hline FRAMEWORK & 5 & 5 & 188.2 \\
\hline TECHNOLOGY & 9 & 8 & 161.44 \\
\hline $\begin{array}{l}\text { CORPORATE SOCIAL } \\
\text { PERFORMANCE }\end{array}$ & 4 & 4 & 94.25 \\
\hline DIFFUSION & 2 & 2 & 124.5 \\
\hline
\end{tabular}

low level of representation in terms of articles and, nevertheless, the average number of quotes is relatively high. This is due to the fact that these articles constitute the starting point in a field that was subsequently developed, as shown in its evolution over time.

In the second period, there are two main topics: PERFORMANCE and MANAGEMENT, one basic and cross-sectional, SUPPLY-CHAIN-MANAGEMENT and one emerging, CAPABILITIES (Figure 4). CORPORATE SOCIAL RESPONSIBILITY and ISO appear as a crosssectional topics.

The complete network in presented in Figure 5. In the period from 2006 to 2010, the central network linked to PERFORMANCE grows in relative importance and maintains its dominant position in the center of the entire network. Next to it, the network in yellow, whose essential component is SUPPLY-CHAIN-MANAGEMENT

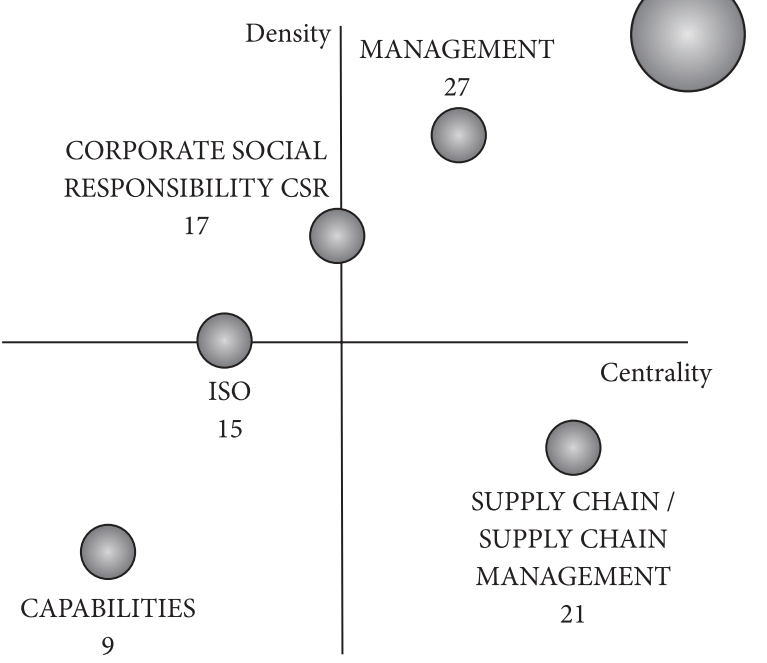

Figure 4. Strategic matrix for second period (2006-2010)

(accompanied by topics linked to Operations) and the MANAGEMENT network (in dark blue, with Innovation and Operations topics) complete the center. Not as central but also relevant, the purple network represents topics related to CORPORATE SOCIAL RESPONSIBILITY, which also become important in these years. Finally, the ISO network has an increasingly greater presence and includes topics related to environmental management systems.

Table 3 presents a substantial increase in the number of articles of non-motor themes. This growth and the

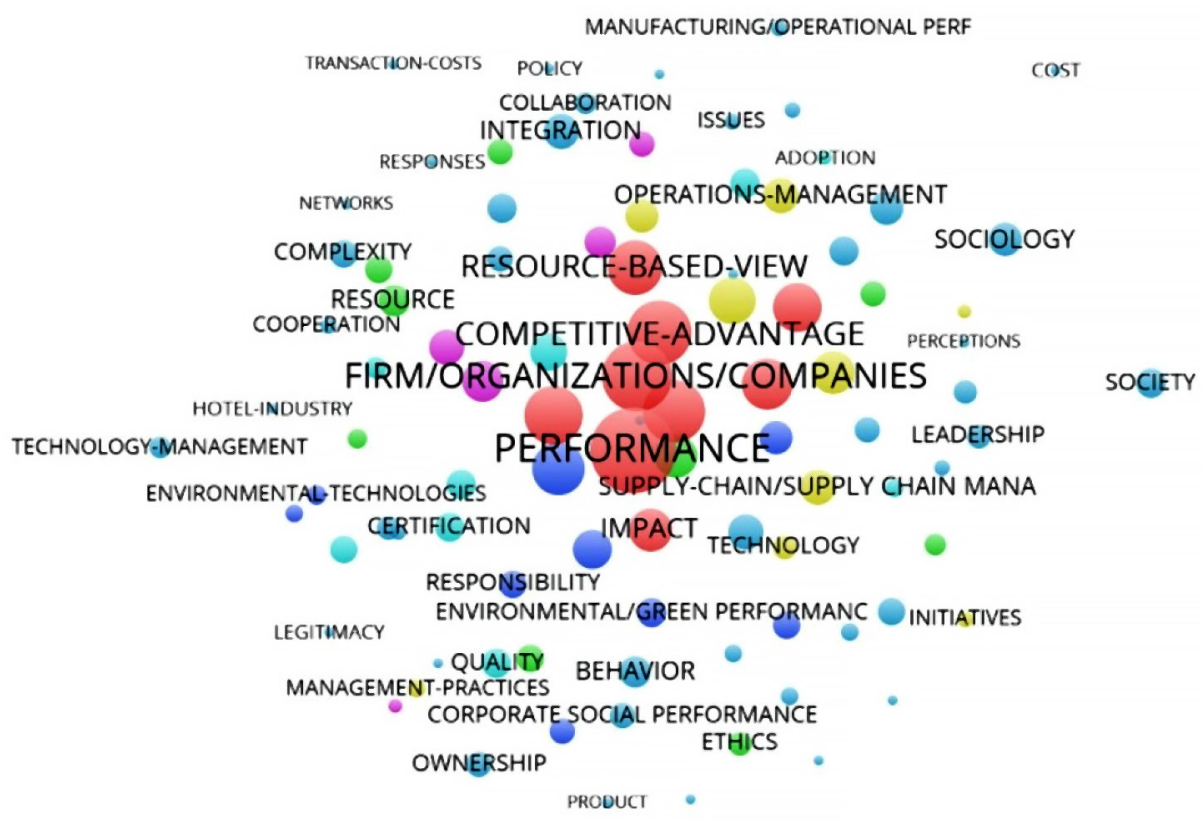

\section{VOSviewer}

STANDARDS

Figure 5. Complete network (2006-2010) 
Table 3. Measurement of topic performance from 2006 to 2010

\begin{tabular}{|l|c|c|c|}
\hline \multicolumn{1}{|c|}{ Theme } & \# articles & $\mathrm{h}$ index & Average quotes \\
\hline PERFORMANCE & 124 & 43 & 48.41 \\
\hline MANAGEMENT & 27 & 16 & 43.44 \\
\hline $\begin{array}{l}\text { SUPPLY-CHAIN/ } \\
\text { SUPPLY-CHAIN- } \\
\text { MANAGEMENT }\end{array}$ & 21 & 16 & 57.1 \\
\hline $\begin{array}{l}\text { CORPORATE SO- } \\
\text { CIAL RESPONSIBI- } \\
\text { LITY }\end{array}$ & 17 & 11 & 40.94 \\
\hline ISO & 15 & 12 & 46.6 \\
\hline CAPABILITIES & 9 & 9 & 48.56 \\
\hline
\end{tabular}

Table 4. Measurement of topic performance from 2011 to 2015

\begin{tabular}{|l|c|c|c|}
\hline \multicolumn{1}{|c|}{ Theme } & \# articles & h index & Average quotes \\
\hline PERFORMANCE & 310 & 27 & 10.16 \\
\hline ISO & 48 & 14 & 10.92 \\
\hline COMMITMENT & 22 & 9 & 7.23 \\
\hline CAPABILITIES & 57 & 12 & 8.19 \\
\hline $\begin{array}{l}\text { EMPIRICAL } \\
\text { RESEARCH }\end{array}$ & 16 & 5 & 8 \\
\hline MODEL & 27 & 9 & 17.48 \\
\hline INFORMATION & 24 & 6 & 8.46 \\
\hline $\begin{array}{l}\text { QUALITY } \\
\text { MANAGEMENT }\end{array}$ & 18 & 6 & 7 \\
\hline $\begin{array}{l}\text { INNOVATION- } \\
\text { MANAGEMENT }\end{array}$ & 15 & 5 & 4.93 \\
\hline RESPONSIBILITY & 12 & 6 & 13.67 \\
\hline $\begin{array}{l}\text { UNITED STATES/ } \\
\text { US }\end{array}$ & 12 & 6 & 15.08 \\
\hline
\end{tabular}

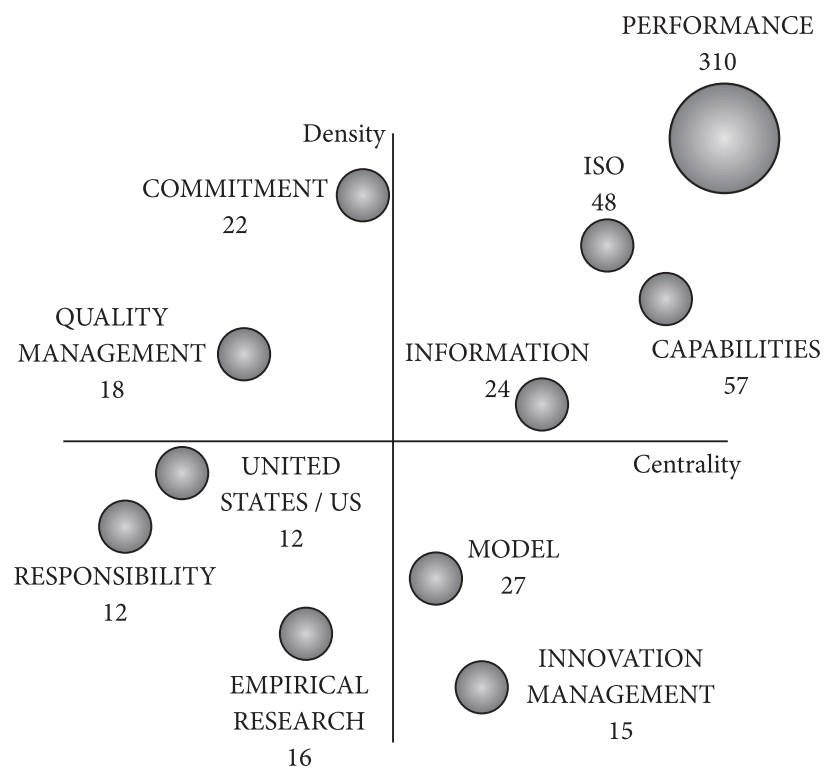

Figure 6. Strategic matrix for second period (2011-2015) proximity in time also have an impact on the reduction of the average number of quotes in these articles and an increase in the $\mathrm{h}$ index. Even so, the figures shown in the Table 3 are those of a developing area.

In the last period, in which we find a more mature situation, PERFORMANCE is accompanied by two others that should be highlighted: CAPABILITIES and ISO (Table 4). ISO appears to be a very dense topic, mainly including topics linked to certification and management systems. INNOVATION-MANAGEMENT is a basic and sectional theme and RESPONSABILITY and EMPIRICAL RESEARCH are emerging themes (Figure 6).

In this last period (Figure 7), the dominance of the motor topic, PERFORMANCE, is at a maximum, although topics such as ISO (in dark blue), which continues to accumulate topics linked to certification and standards, accompany it in the center. There is also room for the RESPONSIBILITY network, which accumulates several topics related to corporate social responsibility, and for QUALITY MANAGEMENT, which maintains OPERATIONS topics, and CAPABILITIES which, together with the central network, brings together central topics in the field of Management, such as the management of strategic alliances and stakeholders.

Figure 8 shows the evolution of topics across three periods of time studied. Continuous lines show a relationship between thematic networks that include the central topic in one of the two networks. Broken lines show relationships that do not meet this condition. The motor topic of PERFORMANCE has clearly continued to grow. In addition to this main topic, the growth of other topics such as ISO and CORPORATE SOCIAL RESPONSIBILITY should be mentioned. ISO also grew clearly and continuously in the last two periods. CORPORATE SOCIAL RESPONSIBILITY still has an important presence and relationship with other thematic networks in the last period.

\section{Discussion}

The results show that the literature on environmental management in the area of Management and Business has focused on six major topics: GREEN/ENVIRONMENTAL/ECOLOGY-ECOLOGICAL, MANAGEMENT, RESOURCE-BASED-VIEW, PERFORMANCE, CORPORATE SOCIAL RESPONSIBILITY and QUALITY MANAGEMENT (particularly ISO). These topics have evolved and become related to others, thus enabling progress in the discipline from the beginning, when it focused on the introduction of a green or environmental dimension and its effects on results, up to the present day in which the management of quality, in particular, the development of ISO regulations and topics related to corporate social responsibility, has acquired a great deal of importance. In addition, we have identified that the "observations" proposed by Bansal and Gao (2006) remain current and some 
CORPORATE SUSTAINABILITY

PERFORMANCE-MEASURES

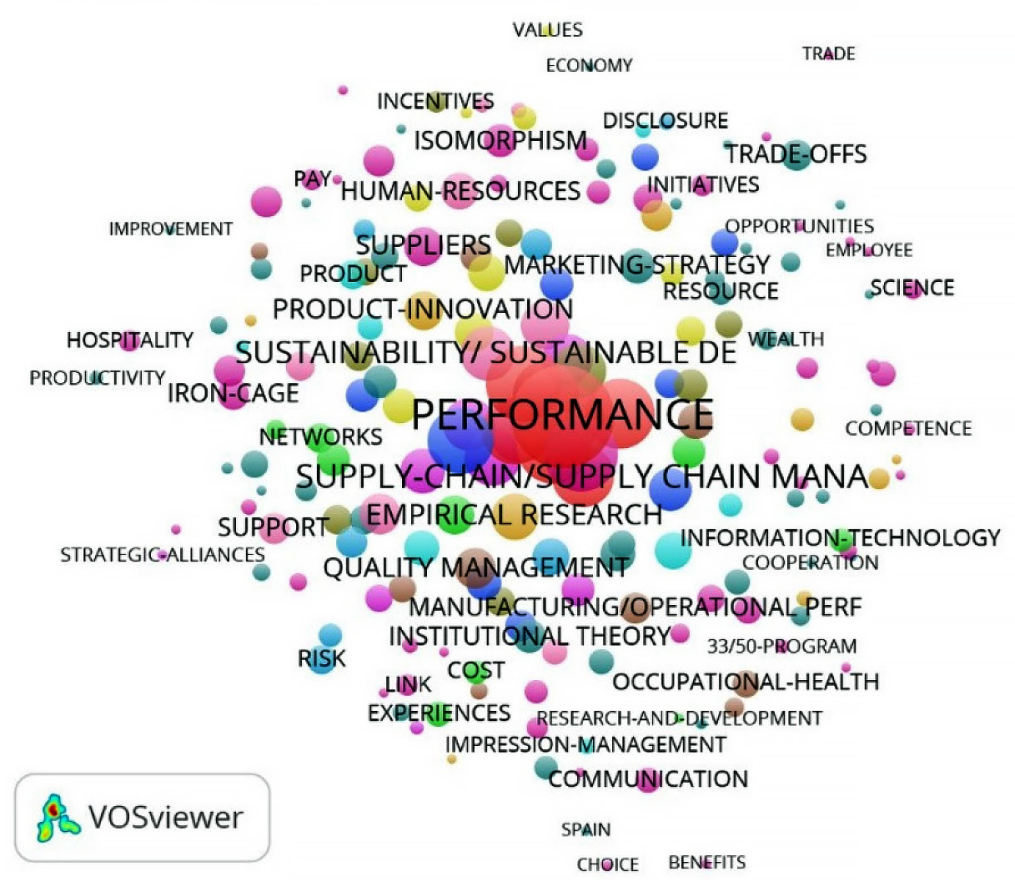

Figure 7. Complete network (2011-2015)

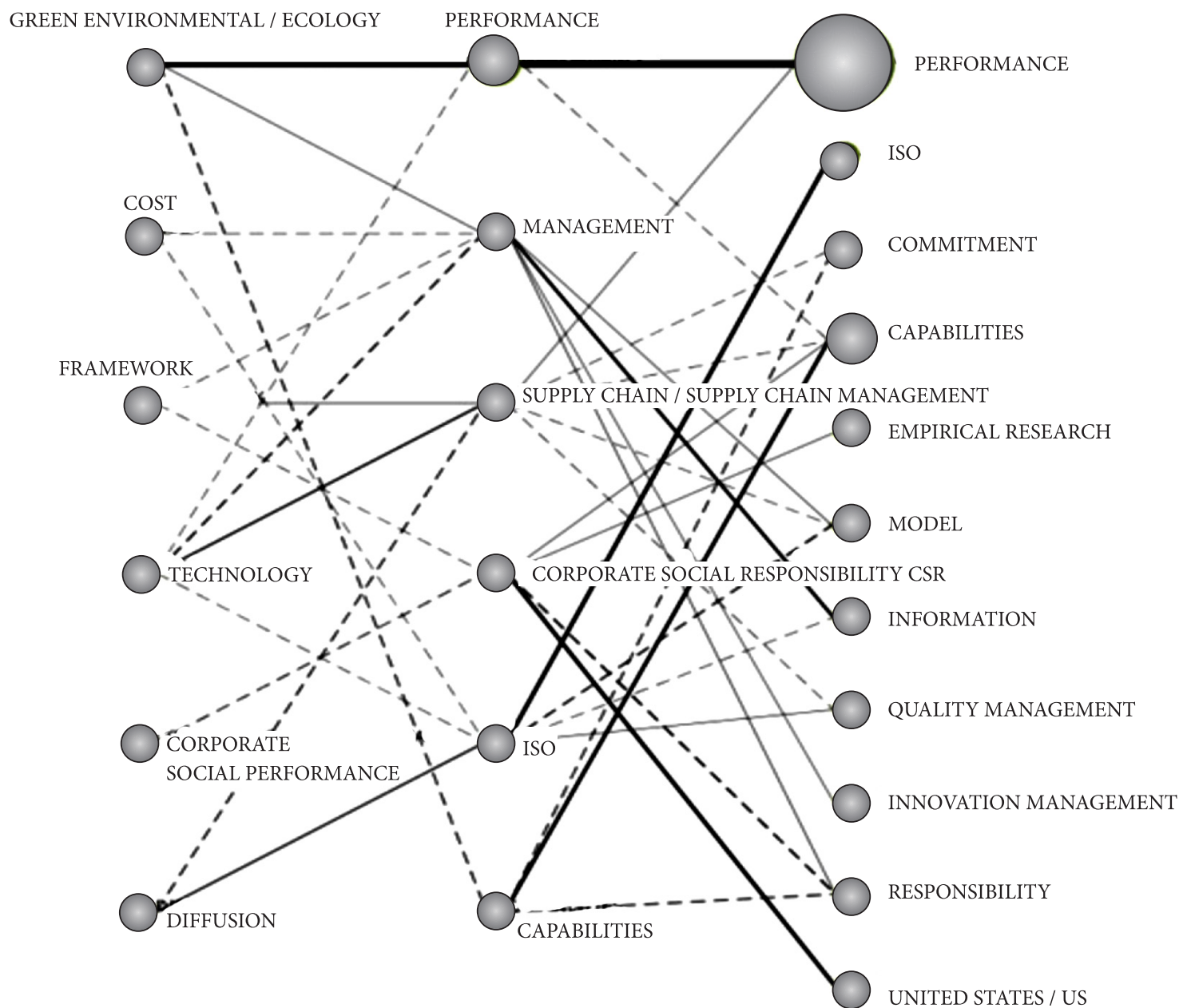


of them have been developed. In that sense, environmental management research has a growing role in the main Management and Business journals. Although previous studies have focused on the analysis of the improvement of environmental performance, recent studies delve deeper into the analysis of the effect of environmental management on organizational performance. Moreover, some studies consider all levels of analysis and use different methodologies.

If we take a closer look at the state of the art, we see the progress that has been achieved in each of the periods analysed. Up to 2005 there are three central topics studied: GREEN/ENVIRONMENT-AL/ECOLOGY-ECOLOGICAL, RESOURCE-BASED-VIEW and PERFORMANCE. There is great interest in including the idea of GREEN/ENVIRONMENT-AL/ECOLOGY-ECOLOGICAL in literature on environmental management. In this regard, Gladwin (1993) invites researchers to determine how "corporate greening" functions, by researching deeper into: what is it?, why?, when?, how?, where does it happen?, who is doing it? and what are its consequences? Other works highlight the importance of considering the natural environment as part of the organization. These works also consider the environmental dimension, in addition to considering political, economic, technological and sociocultural factors (Throop et al. 1993, Shrivastava and Hart 1994).

The development of literature focused on a RESOURCEBASED-VIEW also has its origins in the early research. The first applications and extension of certain theories and approaches to the area of "organizations and the natural environment" appear in this research, especially, the resourcebased-view, which had a major effect on the area after the influential work of Hart (1995), Russo and Fouts (1997) and Aragón-Correa and Sharma (2003). With regard to the term PERFORMANCE, authors such as Porter and Van der Linde (1995) and Hart and Ahuja (1996) highlight one of the research questions that has attracted the most attention in the area: "Does it pay to be green?" According to Bansal and Gao (2006), one of the specific features of this field of study is that many works analyse the influence of environmental management on economic performance, environmental performance or both.

In the period 2005-2010, the topics that stand out are those of PERFORMANCE and MANAGEMENT. During this period, several reviews of literature were published, assigning an important role to the relationship between environmental management and results, be they financial or environmental (Bansal and Gao 2006, Berchicci and King 2007, Etzion 2007, Molina-Azorín et al. 2009a). Topics that began to appear at the beginning of the 90 s continue in this period, as shown by the work of Orsato (2006), MurilloLuna et al. (2008) and Sangle (2010), who research further into the specific nature of environmental strategy, its implementation, causes and consequences.
In the period 2011-2015, the literature focuses its attention on the study of CORPORATE SOCIAL RESPONSIBILITY and QUALITY MANAGEMENT, in particular the analysis of ISO regulations. With regard to CORPORATE SOCIAL-RESPONSIBILITY, Carroll (1979) includes the social responsibilities of companies in four categories: economic, legal, ethical and discretional and uses them in a three-dimensional model of social corporate performance. At the beginning of the period (2011-2015), several articles published in the monograph by Business \& Society magazine dealt with multiple relationships between corporate social responsibility, sustainability and environmental management (Orlitzky et al. 2011).

For the term QUALITY MANAGEMENT, early works deal with the application of environmental management tools, techniques and technology. James (1996) highlights the connections between the objectives and practices of total quality management and environmental management. In this regard, the literature on environmental management systems and quality control systems, especially those that refer to ISO regulations, represent a significant part of the research, especially as of the beginning of the 21st-century (Molina-Azorín et al. 2009b, Delmas and Montes-Sancho 2011, Heras-Saizarbitoria and Boiral 2013).

In the last few years, 2016-2018, papers develop the six topics analysed. Some authors focus their attention on the study of green supply chain management (i.e., Malviya et al. 2018), and environmental management (i.e., Ormazabal et al. 2017) from a resource-based-view (i.e., Brulhart et al. 2017). The study of firm/corporate environment performance (i.e., Escrig-Olmedo et al. 2017, Hartmann and Vachon 2018) and its relationship to other topics such as environmental management systems (i.e., Martín-de Castro et al. 2016) has significant development. Other topics of interest are corporate social responsibility (i.e., Fortis et al. 2018) and environmental management systems (i.e., Biscotti et al. 2018).

The results allow us to propose some future trends. Gessa-Perera et al. (2016) explain the importance of stakeholders' role in business management, and they demand an improvement of organisations' environmental behaviour. Firms, therefore, have the challenge of adopting environmental management practices and strategies that contribute to improved performance. As a result, the study of the strategic management process focused on the environment can be an interesting topic with future research questions such as: What degree of environmental protection can a company have? What are the effects of including the environmental dimension into the mission, vision and objectives of the company? What effects do the stakeholders have on corporate environmental management? What types of environmental strategies exist and what effects do they have on performance? What effects does environmental 
management have on organizational culture? What is the relationship between environmental strategy and organizational change?

\section{Conclusions}

This paper maps the main environmental management topics that have been studied in the Management and Business fields. This map can be a guide for future studies. Berchicci and King (2007) explain that the field of environmental management is located at "the periphery of the management literature". However, we have observed that in the last few years the interest of organizations to be "ecological and responsible with the environment" is changing that situation. We note that the field has grown and matured. Future studies can build on our method and results in three main ways.

First, our method improves the level of clarity and visibility of key relationships. Etzion (2007) states that "the academic literature on organizations and the natural environment is not particularly cohesive. Researchers from various sub-disciplines -Strategy, Economics, Organizational Theory, Policy, Organizational Behaviour, Operations and others - have tackled environmental issues, each utilizing the theories and paradigms afforded by their respective domains of expertise". This situation makes it difficult to synthesize the various insights and theories developed. But the co-word analysis technique we use allows us to identify the main topics that have been studied and their evolution.

Second, our results show the interest of researchers in the last few years to analyse topics such as corporate social responsibility and quality management. This interest derives from the influence of their growing importance to firms. In that sense, Bansal and Gao (2006) find that "Organizations and environment research is theoretically rich and methodologically rigorous" and has important opportunities for growth. Berchicci and King (2007) state the "business and environmental scholars have been willing to break from orthodox disciplinary perspectives" and they explain that "Common property problems, hidden quality attributes, and the importance of extramural knowledge as a source of competitive advantage are all of growing importance in the information age. Evaluating how firms address these challenges will require scholars to rethink disciplinary boundaries, reconsider what is exogenous and endogenous, and re-evaluate what are the fundamental roles for business and governing institutions".

Third, this study has a limited scope because it only considers the journal articles available in WoS. Future studies can use other databases (Scopus, Google Scholar...) and complementary bibliometric techniques such as co-citation analysis to describe the intellectual structure of the research field.
In conclusion, the findings of this paper can improve environmental management research. Future studies will provide important data regarding the importance of environmental issues for company management. Respect of the environment should be an essential responsibility or moral obligation for all companies. Together with this claim is the question of whether companies can become more competitive by protecting the environment. It is therefore necessary to include the environmental dimension in the development and implementation of strategies that minimize the impact of business activity on the environment.

\section{Funding}

This research was supported by the Spanish Ministry of Economy and Competitiveness (Spain) under Project ECO2015-67434-R.

\section{References}

Albertini E (2013) Does environmental management improve financial performance? A meta-analytical review. Organization \& Environment 26 (4): 431-457. https://doi. org/10.1177/1086026613510301

Ambec S, Lanoie P (2008) Does it pay to be green? A systematic overview. The Academy of Management Perspectives 22 (4): 45-62. https://doi.org/10.5465/AMP.2008.35590353

Aragón-Correa JA, Sharma S (2003) A contingent resource-based view of proactive corporate environmental strategy. The Academy of Management Review 28 (1): 71-88. https://doi. org/10.5465/AMR.2003.8925233

Banerjee SB (2001) Managerial perceptions of corporate environmentalism: interpretations from industry and strategic implications for organizations. Journal of Management Studies 38 (4): 489-513. https://doi.org/10.1111/1467-6486.00246

Bansal P, Gao J (2006) Building the future by looking to the past examining research published on organizations and environment. Organization \& Environment 19 (4): 458-478. https:// doi.org/10.1177/1086026606294957

Bansal P, Song H (2016) Similar but not the same: differentiating corporate responsibility from sustainability. Academy of Management Annals 11 (1): 105-149. https://doi.org/10.5465/ annals.2015.0095

Berchicci L, King A (2007) Postcards from the edge: a review of the business and environment literature. Academy of Management Annals 1 (1): 513-547. https://doi. org/10.5465/078559816

Biscotti AM, D’Amico E, Monge F (2018) Do environmental management systems affect the knowledge management process? The impact on the learning evolution and the relevance of organisational context. Journal of Knowledge Management 22 (3): 603-620. https://doi.org/10.1108/JKM-08-2017-0344

Brulhart F, Gherra S, Marais M (2017) Are environmental strategies profitable for companies? The key role of natural competences from a resource-based view. Management Decision 55 (10): 2126-2148. https://doi.org/10.1108/MD-12-2016-0893 
Buysse K, Verbeke A (2003) Proactive environmental strategies: a stakeholder management perspective. Strategic Management Journal 24 (5): 453-470. https://doi.org/10.1002/smj.299

Callon M, Courtial JP, Laville F (1991) Co-word analysis as a tool for describing the network of interactions between basic and technological research: the case of polymer chemistry. Scientometrics 22 (1): 155-205. https://doi.org/10.1007/BF02019280

Carroll AB (1979) A three-dimensional conceptual model of corporate performance. Academy of Management Review 4 (4): 497-505. https://doi.org/10.2307/257850

Choi J, Yi S, Lee KC (2011) Analysis of keyword networks in MIS research and implications for predicting knowledge evolution. Information \& Management 48 (8): 371-381. https://doi. org/10.1016/j.im.2011.09.004

Ciccullo F, Pero M, Caridi M, Gosling J, Purvis L (2018) Integrating the environmental and social sustainability pillars into the lean and agile supply chain management paradigms: a literature review and future research directions. Journal of Cleaner Production 172 (20): 2336-2350. https://doi. org/10.1016/j.jclepro.2017.11.176

Cobo MJ, López-Herrera AG, Herrera-Viedma E, Herrera F (2011) An approach for detecting, quantifying, and visualizing the evolution of a research field: a practical application to the Fuzzy Sets Theory field. Journal of Informetrics 5 (1): 146-166. https://doi.org/10.1016/j.joi.2010.10.002

Cobo MJ, Martínez MA, Gutiérrez-Salcedo M, Fujita H, Herrera-Viedma E (2015) 25 years at knowledge-based systems: a bibliometric analysis. Knowledge-Based Systems 80: 3-13. https://doi.org/10.1016/j.knosys.2014.12.035

Coulter N, Monarch I, Konda S (1998) Software engineering as seen through its research literature: a study in co-word analysis. Journal of the American Society for Information Science 49 (13): 1206-1223. https://doi.org/10.1002/(SICI)10974571(1998)49:13<1206::AID-ASI7>3.0.CO;2-F

Darnall N, Henriques I, Sadorsky P (2010) Adopting proactive environmental strategy: the influence of stakeholders and firm size. Journal of Management Studies 47 (6): 1072-1094. https://doi.org/10.1111/j.1467-6486.2009.00873.x

Delmas M, Montes-Sancho M (2011) An institutional perspective on the diffusion of international management system standards: the case of the environmental management standard ISO 14001. Business Ethics Quarterly 21 (1): 103-132. https:// doi.org/10.5840/beq20112115

Egri CP, Pinfield LT (1996) Organizations and the biosphere: ecologies and environments. In: Clegg SR, Hardy C, Nordn WR (Eds) Managing organizations: current issues. London: Sage Publications. https://doi.org/10.4135/9781446218563.n11

Escrig-Olmedo E, Munoz-Torres MJ, Fernandez-Izquierdo MA, Rivera-Lirio JM (2017) Measuring corporate environmental performance: a methodology for sustainable development. Business Strategy and the Environment 26 (2): 142-162. https://doi.org/10.1002/bse.1904

Etzion D (2007) Research on organizations and the natural environment, 1992-present: a review. Journal of Management 33 (4): 637-664. https://doi.org/10.1177/0149206307302553

Ferenhof HA, Vignochi L, Selig PM, Lezana AGR, Campos LMS (2014) Environmental management systems in small and medium-sized enterprises: an analysis and systematic review. Journal of Cleaner Production 74 (1): 44-53. https:// doi.org/10.1016/j.jclepro.2014.03.027

Fineman S, Clarke K (1996) Green stakeholders: industry interpretations and response. Journal of Management Studies 33 (6): 715-730. https://doi.org/10.1111/j.1467-6486.1996. tb00169.x

Fortis Z, Maon F, Frooman J, Reiner G (2018) Unknown knowns and known unknowns: framing the role of organizational learning in corporate social responsibility development. International Journal of Management Reviews 20 (2): 277-300. https://doi.org/10.1111/ijmr.12130

Gessa-Perera A, García-Vivas S, González-Zamora MM (2016) Valuing environmental management practices through contingent valuation. A review of recent applications. International Journal of Sustainable Society 8 (1): 22-53. https:// doi.org/10.1504/IJSSOC.2016.074949

Gladwin TN (1993) The meaning of greening: a plea for organizational theory. In: Fischer K, Schot J (Eds) Environmental strategies for industry: international perspectives on research needs and policy implications. Washington DC: Island Press.

Guenther E, Endrikat J, Guenther TW (2016) Environmental management control systems: a conceptualization and a review of the empirical evidence. Journal of Cleaner Production 136 (10): 147-171. https://doi.org/10.1016/j.jclepro.2016.02.043

Hart SL (1995) A natural-resource-based view of the firm. Academy of Management Review 20 (4): 986-1014. https://doi. org/10.2307/258963

Hart SL, Ahuja G (1996) Does it pay to be green? An empirical examination of the relationship between emission reduction and firm performance. Business Strategy and the Environment 5 (1): 30-37. https://doi.org/10.1002/(SICI)10990836(199603)5:1<30::AID-BSE38>3.0.CO;2-Q

Hartmann J, Vachon S (2018) Linking environmental management to environmental performance: the interactive role of industry context. Business Strategy and the Environment 27 (3): 359-374. https://doi.org/10.1002/bse.2003

He Q (1999) Knowledge discovery through co-word analysis. Library Trends 48 (1): 133-159. http://hdl.handle.net/2142/8267

Henriques I, Sadorsky P (1999) The relationship between environmental commitment and managerial perceptions of stakeholder importance. Academy of Management Journal 42 (1): 87-99. https://doi.org/10.5465/256876

Heras-Saizarbitoria I, Boiral O (2013) ISO 9001 and ISO 14001: towards a research agenda on management system standards. International Journal of Management Reviews 15 (1): 47-65. https://doi.org/10.1111/j.1468-2370.2012.00334.x

Holt D (2011) Where are they now? Tracking the longitudinal evolution of environmental businesses from the 1990s. Business Strategy and the Environment 20 (4): 238-250. https:// doi.org/10.1002/bse.697

James P (1996) Total quality environmental management and human resource management. In: Wehrmeyer W (Ed) Greening people: human resources and environmental management. New York: Greenleaf Publishing. https://doi.org/10.9774/ GLEAF.978-1-909493-00-1_3

Kostoff R, Eberhart H, Toothman D, Pellenbarg R (1997) Database tomography for technical intelligence: comparative roadmaps of the research impact assessment literature and the Journal 
of the American Chemical Society. Scientometrics 40 (1): 103-138. https://doi.org/10.1007/BF02459264

Law J, Bauin S, Courtial J, Whittaker J (1988) Policy and the mapping of scientific change: a co-word analysis of research into environmental acidification. Scientometrics 14 (3-4): 251-264. https://doi.org/10.1007/BF02020078

Malviya RK, Kant R, Gupta AD (2018) Evaluation and selection of sustainable strategy for green supply chain management implementation. Business Strategy and the Environment 27 (4): 475-502. https://doi.org/10.1002/bse.2016

Martín-de Castro G, Amores-Salvado J, Navas-López JE (2016) Environmental management systems and firm performance: improving firm environmental policy through stakeholder engagement. Corporate Social Responsibility and Environmental Management 23 (4): 243-256. https://doi.org/10.1002/ csr. 1377

Menguc B, Ozanne LK (2005) Challenges of the "green imperative": a natural resource-based approach to the environmental orientation-business performance relationship. Journal of Business Research 58 (4): 430-438. https://doi.org/10.1016/j. jbusres.2003.09.002

Molina-Azorín JF, Claver-Cortés E, López-Gamero MD, Tarí JJ (2009a) Green management and financial performance: a literature review. Management Decision 47 (7): 1080-1100. https://doi.org/10.1108/00251740910978313

Molina-Azorín JF, Tarí JJ, Claver-Cortés E, López-Gamero MD (2009b) Quality management, environmental management and firm performance: a review of empirical studies and issues of integration. International Journal of Management Reviews 11 (2): 197-222. https://doi.org/10.1111/j.14682370.2008.00238.x

Mukherjee B, Chandra B (2018) Conceptualizing green human resource management in predicting employees' green intention and behaviour: a conceptual framework. Prabandhan: Indian Journal of Management 11 (7): 36-48. https://doi. org/10.17010/pijom/2018/v11i7/129940

Murillo-Luna JL, Garcés-Ayerbe C, Rivera-Torres P (2008) Why do patterns of environmental response differ? A stakeholders' pressure approach. Strategic Management Journal 29 (11): 1225-1240. https://doi.org/10.1002/smj.711

Orlitzky M, Siegel DS, Waldman DA (2011) Strategic corporate social responsibility and environmental sustainability. Business \& Society 50 (1): 6-27. https://doi.org/10.1177/ 0007650310394323

Ormazabal M, Rich E, Sarriegi JM, Viles E (2017) Environmental management evolution framework: maturity stages and causal loops. Organization \& Environment 30 (1): 27-50. https://doi.org/10.1177/1086026615623060

Orsato RJ (2006) Competitive environmental strategies: when does it pay to be green? California Management Review 48 (2): 127-143. https://doi.org/10.2307/41166341

Porter ME, Van der Linde C (1995) Toward a new conception of the environment-competitiveness relationship. The Journal of Economic Perspectives 9 (4): 97-118. https://doi.org/10.1257/ jep.9.4.97

Renwick DW, Redman T, Maguire S (2013) Green human resource management: a review and research agenda. International Journal of Management Reviews 15 (1): 1-14. https://doi. org/10.1111/j.1468-2370.2011.00328.x
Russo MV, Fouts PA (1997) A resource-based perspective on corporate environmental performance and profitability. Academy of Management Journal 40 (3): 534-559. www.jstor. org/stable/257052

Salim HK, Padfield R, Hansen SB, Mohamad SE, Yuzir A, Syayuti K, Tham MH, Papargyropoulou E (2018) Global trends in environmental management system and ISO14001 research. Journal of Cleaner Production 170 (1): 645-653. https://doi. org/10.1016/j.jclepro.2017.09.017

Sangle S (2010) Empirical analysis of determinants of adoption of proactive environmental strategies in India. Business Strategy and the Environment 19 (1): 51-63. https://doi.org/10.1002/ bse. 651

Sarkis J, Zhu Q, Lai K (2011) An organizational theoretic review of green supply chain management literature. International Journal of Production Economics 130 (1): 1-15. https://doi. org/10.1016/j.ijpe.2010.11.010

Schaltegger S, Gibassier D, Zvezdov D (2013) Is environmental management accounting a discipline? A bibliometric literature review. Meditari Accountancy Research 21 (1): 4-31. https://doi.org/10.1108/MEDAR-12-2012-0039

Schwartz MS, Carroll AB (2008) Integrating and unifying competing and complementary frameworks. Business \& Society 47 (2): 148-186. https://doi.org/10.1177/0007650306297942

Sharma S (2002) Research in corporate sustainability: what really matters? In: Sharma S, Starik M (Eds) Research in corporate sustainability: the evolving theory and practice of organizations in the natural environment. UK: Edward Elgar Publishing.

Sharma S, Vredenburg H (1998) Proactive corporate environmental strategy and the development of competitively valuable organizational capabilities. Strategic Management Journal 19 (8): 729-753. https://doi.org/10.1002/(SICI)10970266(199808)19:8\%3C729::AID-SMJ967\%3E3.0.CO;2-4

Shrivastava P (1995) The role of corporations in achieving ecological sustainability. Academy of Management Review 20 (4): 936-960. https://doi.org/10.2307/258961

Shrivastava P, Hart S (1994) Greening organizations 2000. International Journal of Public Administration 17 (3-4): 607-635. https://doi.org/10.1080/01900699408524910

Srivastava SK (2007) Green supply-chain management: a stateof-the-art literature review. International Journal of Management Reviews 9 (1): 53-80. https://doi.org/10.1111/j.14682370.2007.00202.x

Tariq S, Jan FA, Ahmad MS (2016) Green employee empowerment: a systematic literature review on state-of-art in green human resource management. Quality and Quantity 50 (1): 237-269. https://doi.org/10.1007/s11135-014-0146-0

Throop, G, Starik, M, Rands, GP (1993) Sustainable strategy in a greening world: integrating the natural environment into strategic management. In: Shrivastava P, Huff A, Dutton JE (Eds) Advances in strategic management (9). Greenwich, CT: JAI Press.

Van Eck NJ, Waltman L (2009) How to normalize co-occurrence data? An analysis of some well-known similarity measures. Journal of the American Society for Information Science \& Technology 60 (8): 1635-1651. https://doi.org/10.1002/ asi. 21075

Van Marrewijk M (2003) Concepts and definitions of CSR and corporate sustainability: between agency and communion. 
Journal of Business Ethics 44 (2-3): 95-105. https://doi.org/ 10.1023/A:1023331212247

Wehrmeyer W (1996) Greening people: human resources and environmental management. Sheffield, England: Greenleaf Publishing.

Wong CY, Wong CWY, Boon-itt S (2015) Integrating environmental management into supply chains: a systematic literature review and theoretical framework International. Journal of Physical Distribution and Logistics Management 45 (1-2): 43-68. https://doi.org/10.1108/IJPDLM-05-2013-0110

Zupic I, Čater T (2015) Bibliometrics methods in management and organizations. Organizational Research Methods 18 (3): 429-472. https://doi.org/10.1177/1094428114562629 